\title{
PENYULUHAN DAN VAKSINASI NEWCASTLE DISEASE PADA AYAM BURAS DI DESA MARGA KECAMATAN MARGA KABUPATEN TABANAN
}

\author{
G.A.Y. Kencana ${ }^{1}$, I.N. Suartha ${ }^{2}$, I.A.P. Apsari ${ }^{3}$, A.A.S. Kendran ${ }^{4}$, I.B.K. Suardana ${ }^{5}$
}

\begin{abstract}
ABSTRAK
Tujuan dilaksanakan pengabdian kepada masyarakat ini adalah untuk mencegah timbulnya penyakit Newcastle Disease pada ayam buras di Desa Marga Dauh Puri, Kecamatan Marga Kabupaten Tabanan. Penyakit ND sangat menular dan dapat menyebabkan kematian tinggi pada unggas. Ayam buras berpotensi sebagai penular penyakit ND karena sistem pemeliharaannya tidak dikandangkan (secara ekstensif). Banjar Ole merupakan bagian dari Desa Marga Dauh Puri, disana banyak dipelihara ayam buras secara ekstensif. Desa Marga Dauh Puri berpotensi tinggi tertular penyakit ND, karena merupakan jalur lalu lintas perdagangan ayam dari Pnebel menuju Denpasar. Kegiatan pengabdian masyarakat dilaksanakan pada tanggal 24 September 2017, meliputi cara beternak ayam dan pencegahan penyakit ND dengan vaksinasi. Tercatat ada 450 ekor ayam buras di Banjar Ole, sebanyak 372 ekor (82.6 \%) berhasil divaksinasi. Hal ini disebabkan beberapa ayam buras tidak dikandangkan sehingga tidak semuanya dapat divaksinasi. Jumlah tersebut sudah cukup memadai untuk cakupan vaksinasi guna menghasilkan kekebalan kelompok. Dari sepuluh sampel ayam buras yang diambil darahnya sebelum divaksinasi ternyata memiliki rataan titer antibodi $2^{2.2} \mathrm{HI}$ unit yang berarti dibawah titer protektif $\left(2^{4} \mathrm{HI}\right.$ unit) sehingga vaksinasi yang dilakukan itu tepat sasaran.
\end{abstract}

Kata kunci: Penyuluhan, vaksinasi, Newcastle Disease, ayam buras, Tabanan.

\begin{abstract}
The purpose of this community service is to prevent the incidence of Newcastle Disease in domestic poultry in Marga Dauh Puri Village, Marga Subdistrict, Tabanan Regency. Newacastle disease is highly contagious and can cause high mortality in poultry. Kampong chickens has the potential as a transmitter of Newcastle disease because the maintenance system is semi extensive. Banjar Ole is part of the village of Marga Dauh Puri, where there are many kampong chickens kept extensively. The village of Marga Dauh Puri is highly potential for contracting Newcastle disease, as it is a chicken trade traffic route from Penebel to Denpasar. Community service activities carried out on September 24, 2017, covering the ways of raising chickens and preventing Newcastle Disease by vaccination. Noted there are 450 poultry in Banjar Ole, as many as 372 $(82.6 \%)$ successfully vaccinated. This is due to some kampong chickens not extensively so not all can be vaccinated. The amount is sufficient for vaccination coverage to produce group immunity. In order to proof that the vaccination program is appropriate, ten blood samples were collected and antibody titer was tested prior vaccination (was found to have a mean antibody titer of $2^{2.2} \mathrm{HI}$ units) which means under protective titer ( $2^{4}$ HI units).
\end{abstract}

Keywords: outreach program, Newcastle Disease, vaccination, kampong chickens, Tabanan

\footnotetext{
${ }^{1}$ Laboratorium Virologi, Fakultas Kedokteran Hewan Universitas Udayana, Denpasar, yuniati_kencana@unud.ac.id

${ }^{2}$ Laboratorium Penyakit Dalam, Fakultas Kedokteran Hewan Universitas Udayana, Denpasar

${ }^{3}$ Laboratorium Parasitologi, Fakultas Kedokteran Hewan Universitas Udayana, Denpasar

${ }^{4}$ Laboratorium Patologi Klinik, Fakultas Kedokteran Hewan Universitas Udayana, Denpasar

${ }^{5}$ Laboratorium Virologi, Fakultas Kedokteran Hewan Universitas Udayana, Denpasar
} 


\section{PENDAhULUAN,}

Desa Marga berada di lingkungan Kecamatan Marga dengan jarak tempuh sekitar 10 menit dari Kota Kecamatan Marga dan berjarak sekitar $12 \mathrm{Km}$ dari Kota Kabupaten Tabanan. Luas wilayah Desa Marga kurang lebih 194,029 Ha. Adapun batas-batas wilayah Desa Marga meliputi :

Sebelah Utara : Desa Marga Dajan Puri

Sebelah Timur : Desa Selanbawak

Sebelah Selatan : Desa Kuwum

Sebelah Barat : Desa Marga Dauh Puri

Ada 4 (enpat) Banjar Dinas di Desa Marga yakni : Banjar Dinas Beng, Tembau, Basa, dan Lebah. Desa Marga Dajan Puri terdiri dari 3 Banjar Dinas yaitu Banjar Dinas Anyar, Bugbugan, dan Tengah. Desa Marga Dauh Puri terdiri dari 2 Banjar Dinas yaitu : Banjar Dinas Ole dan Kelaci. Lokasi Desa Marga berdekatan dengan Kecamatan Penebel (sentra industri peternakan unggas di Kabupaten Tabanan). Lokasi Desa Marga Dauh Puri dan Kemamatan Penebel dapat dilihat pada Gambar 1.

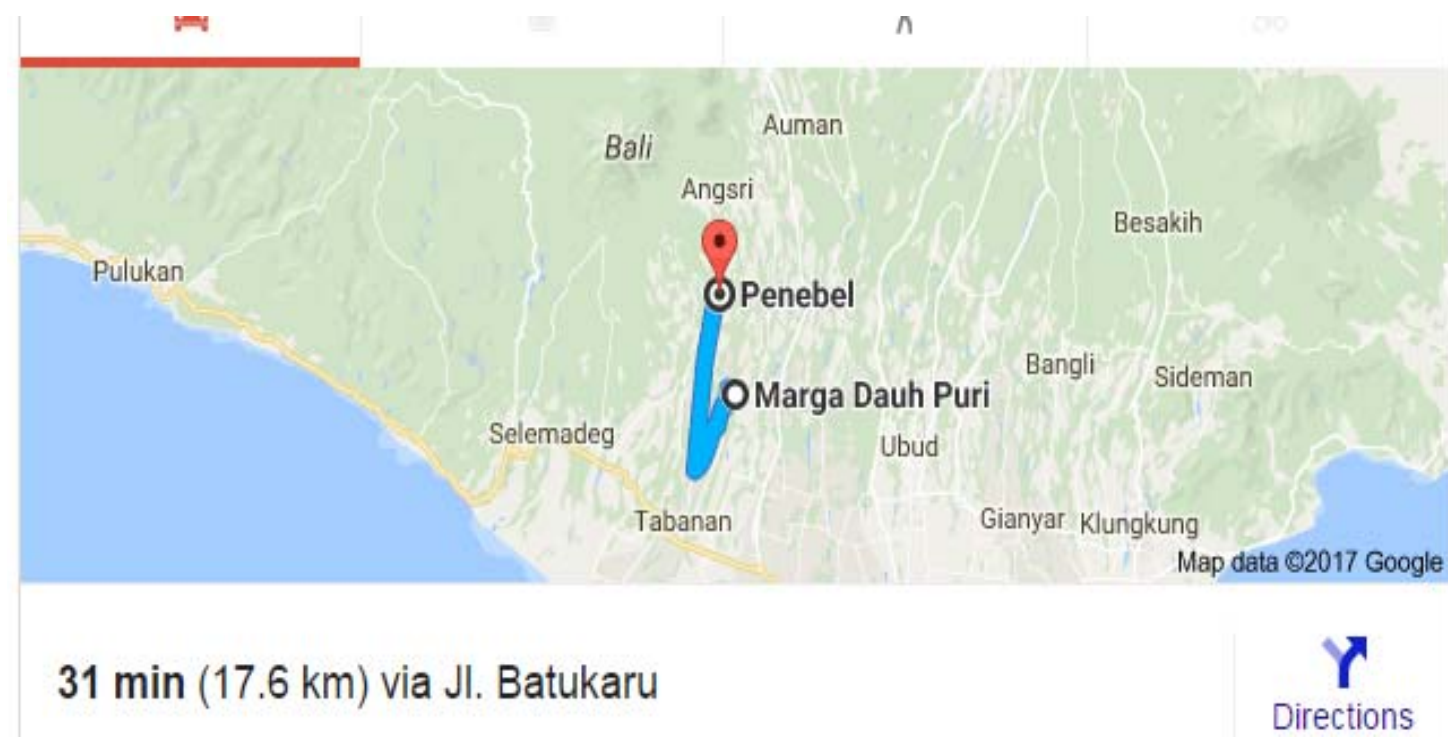

Gambar 1. Lokasi Desa Marga Dauh Puri, Tabanan.

Desa Marga Dauh Puri terletak di Kecamatan Marga, Kabupaten Tabanan, terdiri dari 2 Banjar Dinas yaitu: Banjar Ole, dan Banjar Kelaci. Di Desa Marga Dauh Puri banyak ditemukan ayam buras yang masih dipelihara dengan cara ekstensif (dilepaskan). Cara pemeliharaan ayam yang demikian menyebabkan mudah terjadinya penularan penyakit, baik virus maupun bakteri. Penyakit Newcastle Disease (ND) merupakan salah satu penyakit virus pada unggas yang sangat mudah menular.

Di Indonesia nama penyakit Newcatle disease (ND) lebih dikenal dengan penyakit sebutan penyakit Tetelo. Penyakit ND bersifat endemik pada peternakan ayam, meskipun vaksinasi telah dilakukan secara teratur (Zainudin dan Wibawan, 2009). Newcastle disease merupakan penyakit menular yang bersifat akut sampai kronis pada berbagai unggas dan ditandai dengan gejala gangguan pernafasan, pencernaan dan syaraf. Penyakit ini disebabkan oleh Avian Paramyxovirus type-1(APMV-1), genus Avulavirus dari familia Paramyxoviridae dengan genom RNA serat tunggal (single stranded/ss) dan berpolaritas negative (Aldous dan Alexander, 2001). 


\section{G.A.Y. Kencana, I.N. Suartha, I.A.P. Apsari, A.A.S. Kendran, I.B.K. Suardana}

Kecamatan Penebel Tabanan terkenal sebagai sentra industri peternakan unggas di Kabupaten Tabanan, baik ayam petelur maupun pedaging. Hampir setiap hari terjadi tranportasi unggas dari Penebel menuju Denpasar (baik ke Pasar Beringkit, Pasar Badung dan sekitarnya) melewati. Jalur yang dilalui dari Penebel ke Denpasar adalah melewati Desa Marga termasuk jalan di Desa Marga Dauh Puri.

Wabah penyakit ND maupun Avian Influenza pada ayam sudah pernah dilaporkan di Kecamatan Penebel pada Tahun 2003-2006. Di desa Marga Dauh Puri belum ada laporan penyakit ND. Mengingat lokasi desa Marga Dauh Puri yang sering dilintasi pedagang unggas dari Kecamatan Penebel menuju Denpasar, maka Desa Marga beresiko tinggi tertular penyakit ND melalui tranportasi. Penyakit ND disebarkan melalui udara, maupun cemaran.lainnya yang terbawa saat pedagang unggas melintas di jalan tersebut. Adanya antibodi terhadap virus ND pada ayam yang tidak divaksin menunjukkan bahwa ayam tersebut pernah terinfeksi virus ND. Munculnya antibodi sebagai indikator infeksi virus ND telah dilaporkan oleh beberapa peneliti. Wambura (2010) melaporkan bahwa adanya infeksi virus ND pada berbagai burung liar dengan mengukur titer antibodi, hasilnya adalah titer antibodi HI terhadap virus ND terdeteksi pada $10 \%$ sampai $75 \%$ sampel yang diperiksa.

Meskipun program Pemerintah tentang vaksinasi pada ternak unggas telah digalakkan namun penyakit ND dan AI masih tetap dijumpai di Indonesia (Kencana et al., 2012; Kementan, 2013). Kerugian akibat penyakit ND maupun AI dapat berpengaruh langsung terhadap terhambatnya produksi peternakan ayam (Sudarisman, 2009).

Kegiatan pengabdian ini bertujuan untuk mencegah timbulnya penyakit Newcastle Disease di Desa Marga Dauh Puri khususnya dan di Bali pada umumnya. Kegiatan ini diawali dengan melakukan survey lapangan dan pengambilan sampel serum secara acak di Desa Marga Dauh Puri untuk mengetahui tingkat kekebalan ayam buras di desa tersebut. Pemeriksaan sampel serum dilakukan di Laboratorium Virologi FKH Universitas Udayana.

\section{MATERI DAN METODE}

\subsection{Materi}

Objek sasaran pengabdian masyarakat di Banjar Ole- Marga Dauh Puri adalah kelompok masyarakat peternak ayam buras. Unggas yang divaksinasi adalah ayam buras semua umur.

\subsection{Metode}

Metode yang digunakan dalam kegiatan ini diantaranya adalah: penyuluhan dan vaksinasi ayam buras. Penyuluhan dilakukan dihadapan masyarakat Banjar Ole, Desa Marga Dauh Puri. Metode penyuluhan dilakukan di Bale Banjar dengan cara berdialog langsung. Penjelasan tentang penyakit dan vaksinasi ND juga dilakukan pada saat vaksinasi di rumah penduduk. Pelayanan yang diberikan kepada masyarakat meliputi vaksinasi pada ayam buras yang dilakukan dengan mendatangi rumah penduduk secara door to door. Vaksin yang digunakan adalah vaksin La Sota yang diberikan melalui tetes mata, tetes hidung dan melalui suntikan/ injeksi pada otot paha sesuai dengan aturan dari pabrik vaksin. 


\section{HASIL DAN PEMBAHASAN}

Kegiatan Pengabdian masyarakat yang dilakukan meliputi penyuluhan dan vaksinasi ND pada ayam buras. Penyuluhan penyakit ND dilakukan bertempat di Bale banjar Ole pada tanggal 24 September 2017 yang dihadiri oleh masyarakat peternak ayam buras didampingi oleh Kelian Dinas dan Kelian Adat Banjar Ole. Kegiatan penyluluhan penyakit ND di Banjar Ole Desa Marga Dauh Puri dimuat pada Gambar 2.

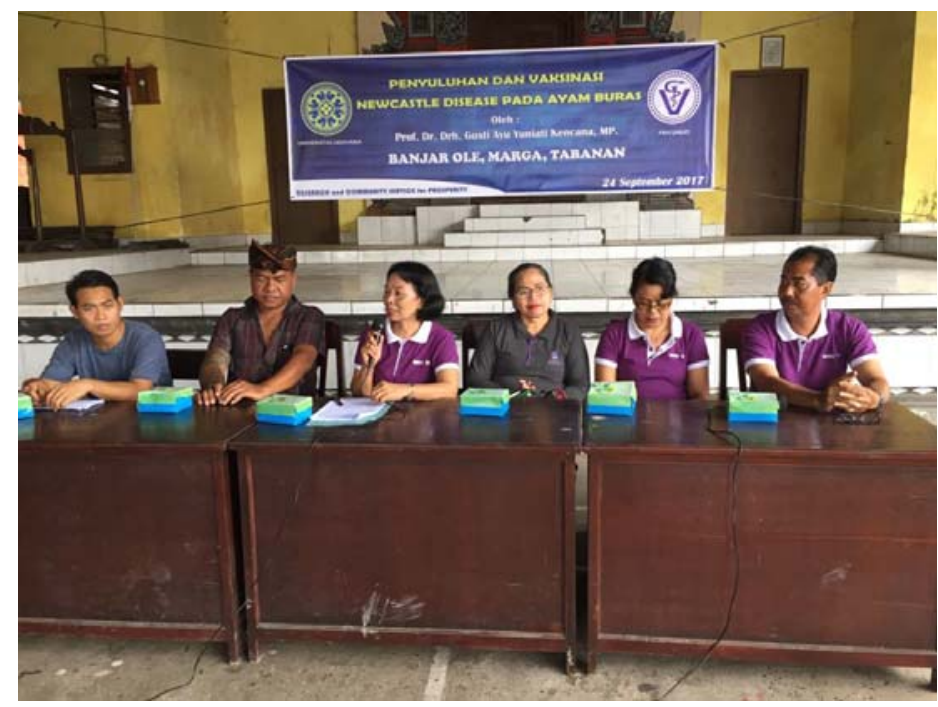

Gambar 2. Penyuluhan ND di Banjar Ole Marga Dauh Puri

Penyuluhan yang diberikan meliputi: penjelasan tentang penyakit ND pada ayam, gejala klinis penyakit ND pada ayam buras, cara penularan dan cara mencegah penyakit ND pada ayam buras. Pada saat penyuluhan juga dilakukan dialog dengan peserta yang dilanjutkan dengan kegiatan vaksinasi ayam buras dari satu rumah ke rumah penduduk lainnya. Hasil wawancara dengan peserta dan Kelian Dinas tercatat jumlah ayam buras di Banjar Ole sebanyak 450 ekor. Sistem pemeliharaan ayam buras di Banjar Ole sebagian besar dikandangkan (sistem intensif) sedangkan sebagian lagi dengan cara dilepaskan (sistem ekstensif).

Vaksinasi ayam buras dilakukan secara door to door dengan mendatangi rumah penduduk yang memiliki ayam buras dari satu rumah ke rumah lainnya. Vaksinasi ND pada ayam dapat dilakukan dengan vaksin aktif, vaksin inaktif berupa sediaan tunggal maupu kombinasi (FOHI, 2007). Sebelum dilakukan vaksinasi, terlebih dahulu dilakukan sampling pengambilan darah (Gambar 3) pada 10 ekor ayam buras untuk diperiksa titer antibodi pra-vaksinasi. Hal tersebut dilakukan guna mengetahui titer antibodi awal yakni titer antibodi sebelum divaksinasi karena titer antibodi yang tinggi dapat menyebabkan kegagalan vaksinasi akibat terjadinya netralisasi. 


\section{G.A.Y. Kencana, I.N. Suartha, I.A.P. Apsari, A.A.S. Kendran, I.B.K. Suardana}

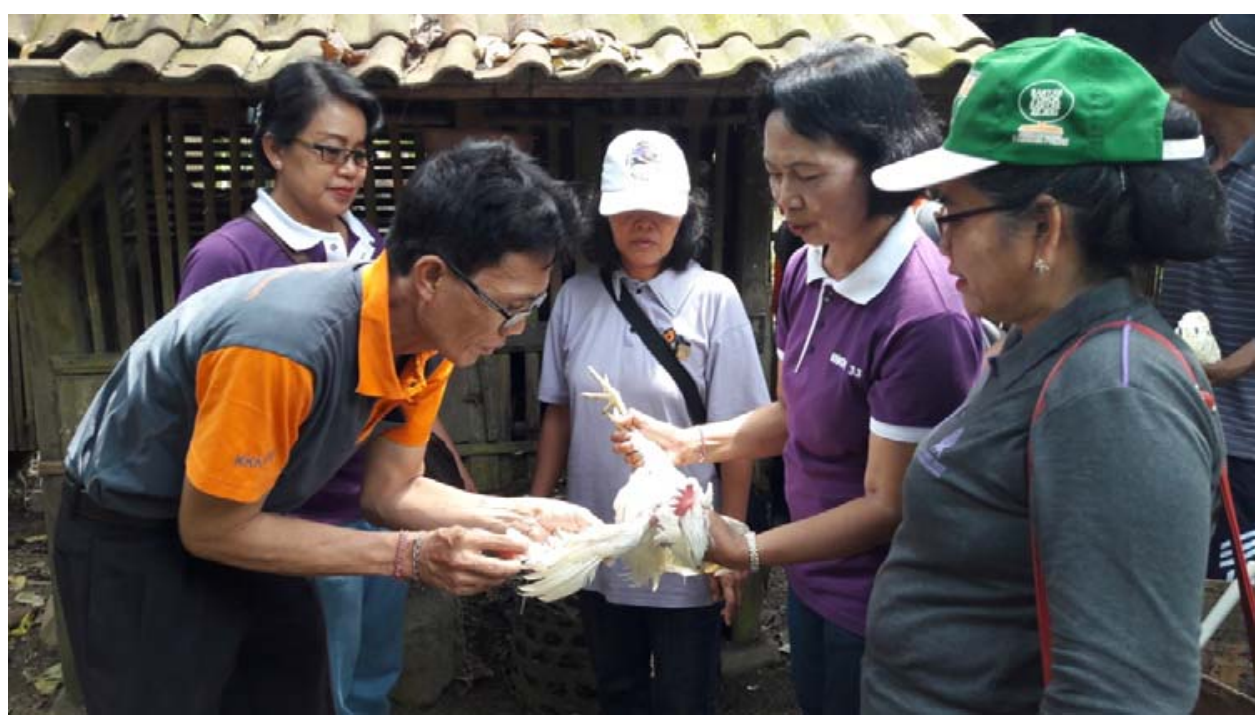

Gambar 3. Darah ayam diambil untuk diperiksa titer antibodi ND pra-vaksinasi

Dari sepuluh sampel serum yang di uji dengan uji Hambatan hemaglutinasi (OIE, 2012) ternyata ayam buras di Banjar Ole memiliki titer antibodi yang tergolong rendah karena titer paling rendah ditemukan adalah $2^{1} \mathrm{HI}$ Unit sedangkan titer tertinggi adalah $2^{6} \mathrm{HI}$ unit dengan rata-rata titer antibodi sebesar $2^{2.2} \mathrm{HI}$ unit. Titer tersebut termasuk kategori titer antibodi tidak protektif, karena titer antibodi dikatakan protektif apabila titernya lebih besar dari $2^{4}$ HI Unit (Permentan, 2008) sehingga harus dilakukan vaksinasi menyeluruh untuk mencegah munculnya kasus ND di Banjar Ole, Marga.

Sebanyak 450 ekor ayam buras tercatat di Banjar Ole, sebanyak 372 ekor ( $82.6 \%$ ) ayam buras yang berhasil divaksinasi. Hal ini disebabkan beberapa ayam buras dilepas/tidak dikandangkan sehingga menyulitkan vaksinasi. Jumlah tersebut sudah cukup memadai untuk cakupan vaksinasi guna menghasilkan kekebalan kelompok. Kegiatan vaksinasi pada ayam buras di Banjar Ole Desa Dauh Puri Marga dimuat pada Gambar 4. 


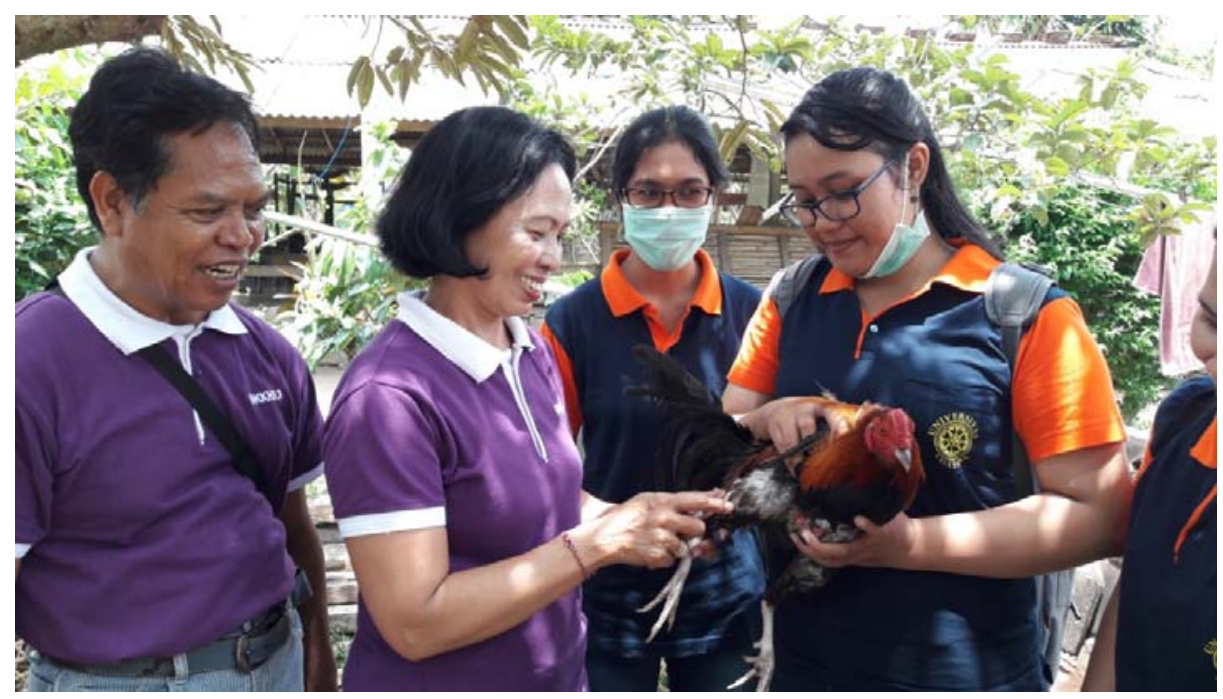

Gambar 4. Kegiatan vaksinasi pada ayam buras di Banjar Ole Marga Dauh Puri Tabanan

Untuk mengetahui pengaruh vaksinasi ND pada ayam buras di Banjar Ole Desa Dauh Puri telah dilakukan pemantauan post vaksinasi, hasilnya tidak ada ayam yang menunjukkan gangguan kesehatan post vaksinasi. Selaian pemantauan terhadap gejala klinis, lebih baik jika dilakukan pemeriksaan titer antibodi post vaksinasi untuk mengetahui keberhasilan vaksinasi ND di Banjar Ole.

\section{SIMPULAN DAN SARAN}

Disimpulkan bahwa masyarakat antusias mengikuti kegiatan penyuluhan dan vaksinasi ND pada ayam buras untuk kesehatan ayam peliharaannya dan berperan serta aktif dalam kegiatan pelayanan vaksinasi yang dilakukan oleh Tim dari FKH Udayana, Hasil pemeriksaan rataan titer antibodi ayam buras yang diambil sebelum divaksinasi adalah sebesar $2^{2.2} \mathrm{HI}$ Unit (dibawah titer protektif) sehingga vaksinasi yang diberikan itu tepat sasaran.

Monitoring post vaksinasi ND perlu dilakukan guna mengetahui keberhasilan vaksinasi di Banjar Ole. Untuk mencegah penyakit ND maka perlu dilakukan vaksinasi ulangan secara berkesinambungan pada ayam buras.

\section{UCAPAN TERIMAKASIH}

Penulis mengucapkan terimakasih kepada LPPM Universitas Udayana dan Pemerintah Republik Indonesia atas Dana DIPA PNBP Universitas Udayana Tahun Anggaran 2017. Sesuai dengan Surat Perjanjian Penugasan Pelaksanaan Pengabdian kepada Masyarakat Udayana Mengabdi Nomor: 67486/UN14.4.A/PM/2017, tanggal 12 Juli 2017. 
G.A.Y. Kencana, I.N. Suartha, I.A.P. Apsari, A.A.S. Kendran, I.B.K. Suardana

\section{DAFTAR PUSTAKA}

Aldous EW, Alexander DJ. 2001. Detection and differentiation of Newcastle disease virus (avian paramyxovirus type1). Avian Pathol., 30: 117-128.

Alexander DJ. 2001. Newcastle Disease. The Gordon Memorial Lecture. Br. Poult. Sci. 42, 5-22.

(FOHI) Farmakope Obat Hewan Indonesia. 2007. Jilid I (Sediaan Biologik). Edisi 3. Jenderal Peternakan. Departemen Pertanian Republik Indonesia. Hlm 59-60, 79-80, 124-125.

Kencana GAY, Kardena IM, Mahardika IGNK. 2012 a Peneguhan Diagnosis Penyakit Newcastle Disease Lapang pada Ayam Buras di Bali Menggunakan Teknik RTPCR. J Kedokteran Hewan 6(1): 28-31.

Kencana GAY, Mahardika IGNK, Suardana IBK, Mantik Astawa IN, Krisna Dewi NM, Narendra Putra GN. 2012. Pelacakan Kasus Flu Burung Pada Ayam dengan Reverse Trancriptase Polymerase Chain Reaction. J Veteriner 13(3): 303-308.

Kencana GAY, Suartha IN, Mesakh PS, Handayan AN, Steffi Ong, Syamsidar, Kusumastuti A. 2015. Respons Antibodi terhadap Penyakit Tetelo pada Ayam yang Divaksin Tetelo dan Tetelo-Flu Burung. J. Veteriner 16(2): 283-290

(OIE) Office International Des Epizooties. 2012. Manual of Diagnostic Test and Vaccines for Terresterial Animal Chapter.Capter 2.3.14. Newcastle Disease. Hlm.1-9 www.oie.int. Diakses tgl 02 Nopember 2017.

(Permentan) Peraturan Menteri Pertanian. 2008. Pedoman Penataan Kompartemen dan Penataan Zona Usaha Perunggasan. Nomor 28/Permentan/OT.140/5/2008. www.perundangan.pertanian.go.id. Diakses tgl 30 Nopember 2017.

Sudarisman. 2009. Pengaruh Perkembangan Sistem Produksi Ayam terhadap Perubahan Genetik dan Biologik Virus Newcastle Disease. Wartazoa 9(3): 1

Wambura PN. 2010. Detection of antibody to Newcastle disease virusin semidomesticated free-range birds (Numida meleagris an Columba livia domestica) and the risk of transmission of Newcastle disease to village chickens-short communication. Veterinaski Arhiv 80 (1): 129-134.

Zainudin D, dan Wibawan IWT. 2009. Biosekuriti dan managemen penyakit ayam lokal. Available at http://www.scribd.com/doc/1698 5320/biosekuriti-ayam-lokal Accessed 20 Sep 2011. 